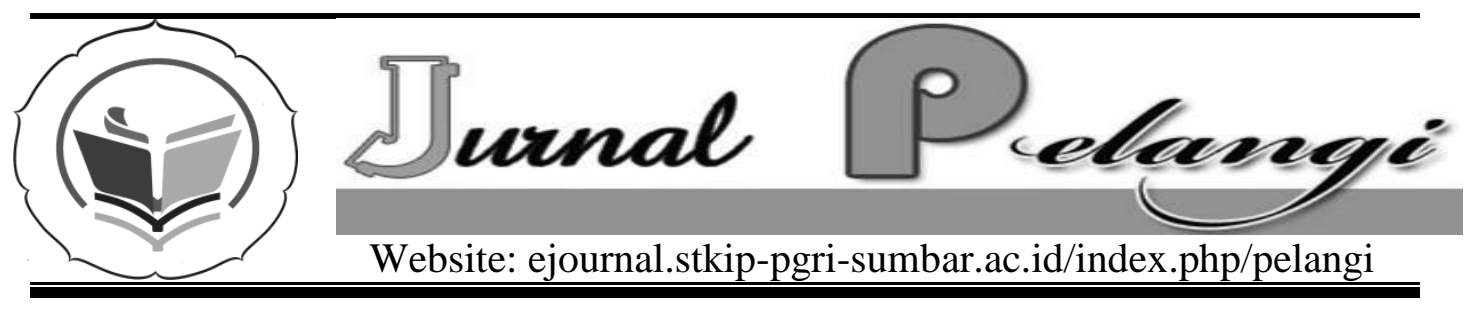

\title{
IMPROVING STUDENTS' VOCABULARY MASTERY BY USING VOCABULARY NOTEBOOKS AT GRADE V. C. OF SDN 025 BUKIT RAYA PEKANBARU
}

Melvina dan Siti Nurbaya

STKIP PGRI Sumatera Barat

Melivina.amir@yahoo.com

INFO ARTIKEL

Diterima :01-01-2014

Disetujui :01-12-2014

Kata Kunci:

classroom action research vocabulary mastery vocabulary notebook
Keywords:

classroom action research vocabulary mastery vocabulary notebook

\section{Abstrak}

Penelitian ini mengkaji tentang permalahan siswa dalam keterampilan berbahasa. Peneliti menemukan siswa-siswi kelas V.C SDN 025 Bukit Raya Pekanbaru memiliki masalah dalam kosa kata mereka. Sebagai solusi, peneliti melakukan Penelitian Tindakan Kelas (PTK) untuk mengaplikasikan sebuah teknik, vocabulary notebooks. Penelitian ini dilakukan dalam dua siklus. Peneliti dibantu oleh kolaborator dalam mengumpulkan data yang diperoleh melalui observasi, catatan lapangan, test, dan wawancara.Hasil penelitian menunjukkan adanya peningkatan kemampuan penguasaan kosa kata siswa-siswi dengan menggunakan vocabulary notebook.

\section{Abstract}

This research examines the student's problem in language skills. The researcher finds that VC-grade students of SDN 025 Bukit Raya Pekanbaru have problems in their vocabulary. As the solution, the researcher conducted a Class Action Research (CAR) to apply a technique called vocabulary notebooks. This research was conducted in two cycles. Researchers helped by collaborators in collecting data through observation, field notes, test, and interview. The results shows that there is an increased ability to master the vocabulary for the students by using vocabulary notebook. 


\section{INTRODUCTION}

The objective of teaching English in elementary school is to prepare children to have competition value in global era and to introduce English at early ages. Vocabulary is one of elements of the language that should be learned and taught. It will be hard to master language without mastery of understand certain numbers of vocabularies. Vocabulary mastery is one of the components to master English. The students should have ability in understanding and using the words and meaning. The students not only know the words, but also the meaning. It is also plays an important part in English skills; listening, speaking, reading, and writing. The larger vocabulary the students master, the easier they develop the English language skills. In other words, limited vocabulary mastery inhibits the students to the develop the language skills well.

Furthermore, the teaching vocabulary for elementary school needs appropriate technique in order that the students do not feel bored and they become active in classroom. The teachers can apply some games, media, learning strategies or other teaching techniques to make the teaching and learning process more effective. In addition, by applying the appropriate teaching technique, the students are enjoyable in teaching and learning activities. So, the teaching techniques are very important for the students' better improvement in their learning.

However, the English teaching at grade V.C of SDN 025 Bukit Raya Pekanbaru is not effective yet. Based on the result of observation with the teacher in the class on January $26^{\text {th }}$ 2011 most of the students in the school particularly in the class V.C had less vocabulary. It make most the students cannot reach the curriculum target of English minimum score (75). It caused by many factors, they are belonging to the students also to the teacher's problem. Moreover, the students' problems are; lack of vocabulary makes them feel difficult in learning English; they still feel strange with the word, they are afraid of mistake in saying or uttering the English word. Then, the teacher's problem are; the techniques that teacher used do not motivate the students in learning English, the teacher only uses a text book and a book exercises as media for teaching English to the students. It implies toward the students' learning process. They are not serious in following the lesson. Another problem comes from the teacher is the teacher only give a little time to practice the correct pronunciation of the word. It also makes the students become low in mastering vocabulary. So, those problems above implies toward the student' low vocabulary mastery.

Based on the problem above, it probably can be solved by using the 
appropriate teaching technique, the researcher chooses "Vocabulary Notebooks". The vocabulary notebooks is a kind of teaching and learning strategy to provide the learners with an area of language learning where they could be given a relatively high level of independence that would build their confidence their ability to act independently of the teacher (Schmit, 1997). He also states the vocabulary notebooks is also as one ways of helping students to engage more meaningfully with the words that they were being exposed in their language learning experiences and to increase the learners' lexical competence. In addition, (Gairns and Redman 1986, Lewis 1993, and Schmitt and McCharty 1997) state that learning vocabulary through vocabulary notebook can help the learner to develop the skills for processing and learning new lexical items. This reflects the currents acknowledgement of the importance of lexis and lexical competence in applied linguistics, language learning methodology, language teaching materials. In addition, they also state that by applying the vocabulary notebook in teaching learning activity can engage more meaningfully with the new word that they were being exposed in their language learning experiences. And, they also state the vocabulary notebook aim to increase the learners' competence. So, from the some experts' ideas above, it can be concluded that teaching and learning process by using vocabulary notebook contribute many advantages. It can improve or increase the students' vocabulary mastery.

\section{Teaching Vocabulary by Using Vocabulary Notebooks}

Teaching vocabulary in the level of elementary integrated in the four language skill; listening, speaking, reading, and writing. To build up the four language skills, vocabulary is strongly needed. Limited vocabulary mastery will inhibit the students to develop the language skills. Moreover, according to Schmitt and Schmitt (1995) there are some steps or ways in implementing or applying the vocabulary notebooks technique in the teaching and learning process. The steps as follows:

1. The teacher working on the program about how the vocabulary notebooks would be implemented

2. Discussing the modes of defining and explaining vocabulary including; parts of speech, pronunciation information, English example in sentence. Synonym and antonym, mind maps

3. Explaining the concept of vocabulary notebooks

4. Working on the vocabulary notebooks.

5. Stronger individuals and groups quickly grasp.

6. Providing charts with various stickers for different kinds of 
achievement in the vocabulary notebooks seemed to increase motivation levels.

7. Vocabulary notebooks had become a key part of the program in the center and including them in the continues assessments of the students.

Based on statement given by the expert above, it can be concluded that there are seven steps or ways in applying the vocabulary notebooks in the teaching and learning activity. They are; the teacher explains about how to apply the vocabulary notebooks in the teaching and learning process, define and explain vocabulary including; part of speech, pronunciation information, English example in sentence, synonym and antonym, and mind maps, explaining the concept of vocabulary notebooks, stronger individuals and groups quickly grasp, providing charts with various stickers for different kinds of achievement in the vocabulary notebook seemed to increase motivation levels, and include the vocabulary in the continuous assessment of the students. In addition all of those steps above are greatly needed to be implemented by the teacher and students during conducting the teaching and learning activities.

\section{METHOD OF THE RESEARCH}

The type of this research was Classroom Action Research. According to Mills (2003) classroom action research is "systematic inquiry conducted by teacher researchers, principals, school counselors, or other stakeholders in the teaching learning environment to gather information about how their particular schools operate, how they teach, and how well their students learn". The participants of this research were the students at grade V.C of SDN 025 Bukit Raya Pekanbaru that consists of 32 students (16 males and 16 females). The researcher used two cycles in this research. Every cycle had four steps: planning, doing action, observing and reflecting.

To collect the above data of the research, the direct observation was conducted. The data was collected in order to find out what happening while implementing Vocabulary notebooks in teaching English. To gain the data, the collaborator used observation checklist, test, interview, and field notes during the observation. They were for observing teacher and students during the action.

Then, after doing the action, the researcher gave the vocabulary test at the end of the cycle to see students' improvement in vocabulary mastery. Each test was showed in the graphic forms. The results of students' vocabulary test were also used as data sources. Then, they were analyzed by using assessment of scoring aspect in vocabulary mastery.

After collecting the data, those were analyzed quantitative and 
qualitatively. It was analyzed by the researcher, collaborator, and the raters.

1. Quantitative

The data gotten from the result of the test was analyzed by using formula of average or mean score. After that, the vocabulary mastery score was presented by using a diagram. The formula of mean score that is used to analyze the result of the test as in the Sudijono (2008) suggested:
$M x=\frac{\sum X}{N}$
$M x=$ Mean
$\sum X=$ Total score
$N=$ Number of cases

After the researcher adopted the formula above, the researcher referred to Kriteria Ketuntasan Minimum (KKM) of the school to identify the students' level of the students' mean score in vocabulary mastery. The mean score was reflected into the score category as in the foolowing table:

Table 1: The Level of the Students' Score

\begin{tabular}{|c|c|}
\hline Interval & Categories \\
\hline $86-100$ & Very Good \\
\hline $71-85$ & Good \\
\hline $56-70$ & Fair \\
\hline $10-55$ & Poor \\
\hline
\end{tabular}

(Sutanto Leo, 2006: xix)

2. Qualitative

The data gotten from observation, interview, and field note were analyzed through some processes of qualitative data analysis, they are: data managing, reading/ memoing, description, classifying, and interpreting (Gay, 2000).

\section{FINDINGS AND DISCUSSION}

Based on the purposes of the research, this classroom action research was conducted to find out whether the vocabulary notebooks can better improve the students' vocabulary mastery and the factors influence the improvement of the students' vocabulary mastery by using the vocabulary notebooks technique.

\section{The result of the Base Score}

Before conducting the research, the researcher had given the students pre test. It aimed to get the base score about the students' vocabulary condition and the way the students learn English. From the pre test result, it was summarized that most of the students had problem in vocabulary mastery. The results of the students vocabulary mastery from base score is presented below: 
Table 2: Students' Vocabulary Mastery Base Score of Average score

\begin{tabular}{|c|l|c|c|}
\hline No & \multicolumn{1}{|c|}{ Indicators } & Average $\left(\mathbf{M}_{\mathbf{x}}\right)$ & Category \\
\hline 1 & Noun & 70.00 & Fair \\
\hline 2 & Pronoun & 59.38 & Fair \\
\hline 3 & Adjective & 56.25 & Fair \\
\hline 4 & Verb & 60.63 & Fair \\
\hline 5 & Preposition & 59.37 & Fair \\
\hline
\end{tabular}

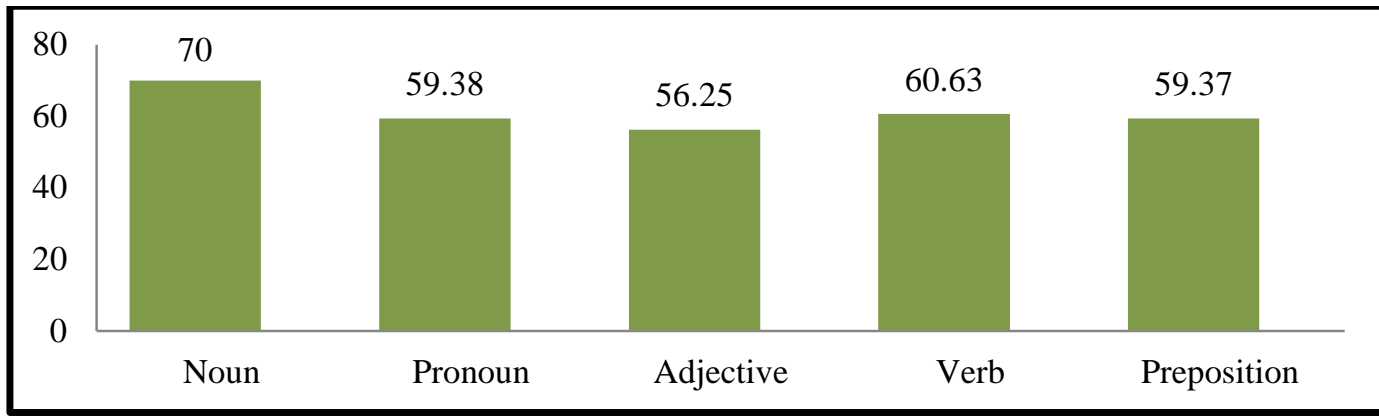

Ficture 1:Students' Vocabulary Mastery Base Score of Average score

Referring to table 2 and diagram 1 above, it can be concluded that be students' vocabulary mastery were commonly fair. The students' vocabulary mastery for "Noun" was $70.00 \%$. it was categorized into "Fair" score category. It could be identified that the students had no difficulty it terms of noun. The students' vocabulary mastery for "Pronoun" was 59.38\%. It was categorized into "Fair" score category. It could be identified that the students had no difficulty in term of pronoun. The students' vocabulary mastery for "Adjective" was $56.25 \%$. It was categorized into "Fair" score category. In term "Verb" was $60.63 \%$. It was categorized into "Fair" Score category. The students' vocabulary mastery for "Preposition" was $59.37 \%$. It was categorized into "Fair" score category. It could be identified that they had problems in term of preposition.

\section{The Result of the Cycle I}

From the situation above, it can be conclude that all of the students' vocabulary mastery indicators were commonly fair. This score was gotten from the pre test, whereas the average of the score 59.37 below KKM. In short, from the clarification above, it could be concluded that the students have low vocabulary mastery. The improvement of the student's vocabulary mastery can be seen after looking at bellow by using vocabulary notebooks. 
Table 3: Vocabulary Mastery Test Result of Average for Cycle I

\begin{tabular}{|c|l|c|c|}
\hline No & \multicolumn{1}{|c|}{ Indicators } & Average $\left(\mathbf{M}_{\mathbf{x}}\right)$ & Category \\
\hline 1 & Noun & 76.25 & Good \\
\hline 2 & Pronoun & 66.88 & Fair \\
\hline 3 & Adjective & 65.63 & Fair \\
\hline 4 & Verb & 69.38 & Fair \\
\hline 5 & Preposition & 63.12 & Fair \\
\hline
\end{tabular}

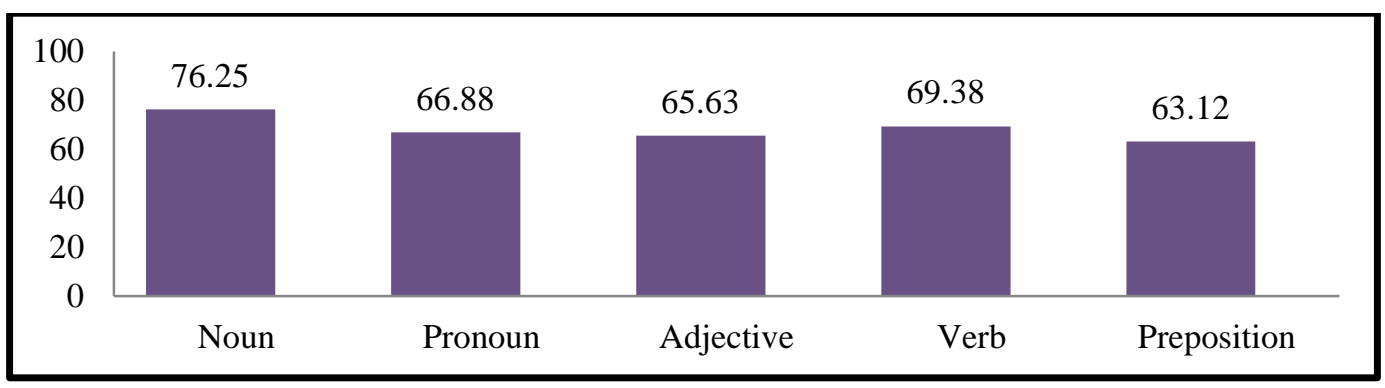

Ficture 2:Students' Vocabulary Mastery Test Result of Average For Cycle I

Table 3 and diagram 2 above showed the results of the students' vocabulary mastery in cycle I test. From this table, it could be identified that the students' vocabulary mastery were commonly fair. It could be identified that the students' vocabulary for Noun was $76.25 \%$. It was categorized into "Good" score category. They had an improvement from pre test to cycle I test. For "Pronoun" they got $66.88 \%$. It was categorized into "Fair" score category. For "Adjective" they got $65.63 \%$. It was categorized into "Fair" score category. For "Verb" they got $69.38 \%$. It was also categorized into "Fair" score category. In "Preposition" they got $63.12 \%$. It was categorized into "Fair" score category. It could be identified that they had an improvement from pre test to cycle I test.

\section{The result of the cycle II}

Referring to the result of the cycle I test above the researcher got a conclusion that the students' test result of all indicators was higher than base score, but there is no significant changing of all indicators. It because the students did not understand well about the material, it means that they still had problem in vocabulary mastery. The average of score was 65.21 below KKM. So, the students' vocabulary mastery activities by using vocabulary notebooks were still the focus of the researcher and collaborator to be improved in cycle II. 
Table 4: Vocabulary Mastery Test Result of Average Score For Cycle II

\begin{tabular}{|c|l|c|c|}
\hline No & \multicolumn{1}{|c|}{ Indicators } & Average $\left(\mathbf{M}_{\mathbf{x}}\right)$ & Category \\
\hline 1 & Noun & 84.38 & Good \\
\hline 2 & Pronoun & 71.88 & Good \\
\hline 3 & Adjective & 83.13 & Good \\
\hline 4 & Verb & 78.12 & Good \\
\hline 5 & Preposition & 76.88 & Good \\
\hline
\end{tabular}

\begin{tabular}{|c|c|c|c|c|c|}
\hline & 84.38 & 718 & 83.13 & 78.12 & 76.88 \\
\hline 60 & & & & & \\
\hline 40 & & & & & \\
\hline 20 & & & & & \\
\hline & Noun & Pronoun & Adjecti & Verb & Prepos \\
\hline
\end{tabular}

Ficture 3: Students' Vocabulary Mastery Test Result of Average Score For Cycle II

Table 4 and diagram 3 above showed the results of the students' vocabulary mastery in cycle II test. From the above table and figure, it could be identified that the students' vocabulary mastery were commonly "Good". It could be identified that they improvement in cycle II. Moreover, the students' vocabulary mastery for "Noun" was $84.38 \%$. It was categorized into "Good" score category. They had an improvement compared to the previous cycle. For "Pronoun" they got $71.88 \%$. It was categorized into "Good" score category. It was higher than the result of pre test and cycle I. It was categorized into "Poor" score category. In term of "Preposition" they got $76.88 \%$. It was categorized into "Good" score categorized. It means that the students' score of all indicators in cycle II was better than cycle $I$. in short, after having a test at meeting four, the students vocabulary mastery got better than previous cycle.

Referring to the result of the cycle II test above, the researcher got a conclusion that the students' vocabulary mastery was improved. Furthermore, the score of the students' vocabulary mastery proficiency always changed from one to the others. It could be identified that there was a significant effect of using vocabulary notebooks toward the students' vocabulary mastery. But, for "Pronoun" they got 71.88. It was categorized into "Good" score category. The score of pronoun still under the KKM. It could be identified that the students had difficult in term of pronoun. In short, the researcher and collaborator decided to take the research data until cycle II only.

\section{Discussion}

As explained previously, this action research was conducted in two 
cycles. Each cycle had four meetings including a test at the end of the cycle. It was 70 minutes for each meeting. This research has been done at the grade V.C of SDN 025 Bukit Raya Pekanbaru. Before carrying out this research, researcher analyzed the base data score about the students' vocabulary mastery condition and the way students learn English. After analyzed the base data score result. The researcher found that the students' had low in vocabulary mastery.

In order to overcome the students' problem in vocabulary mastery, the researcher implemented vocabulary notebooks to find out the extent of vocabulary notebooks to improve the student's vocabulary mastery and the factors influenced the improvement of the students' vocabulary mastery. It was supported by the result of the students' test in each cycle, observation checklist, field notes, and interview. In addition, the clarification of the improvement of the students' vocabulary mastery and the influence of the vocabulary notebooks to improve students' vocabulary mastery can be seen as bellow:

1. The extent to which vocabulary notebooks could better improve the students' vocabulary mastery.

From the vocabulary mastery test given before conducting the classroom action research and test given in cycle I and cycle II, the used of vocabulary notebooks was able to improve the students' vocabulary mastery. It was found that the result of the students' vocabulary score test increased in cycle II. The comparison of the result in all of the tests can be presented as in the following:

Table 5: The Comparison of Students' Vocabulary Mastery Score from Based Score to Cycle II

\begin{tabular}{|c|l|c|c|c|}
\hline No & Indicators & $\begin{array}{c}\text { Students' } \\
\text { Vocabulary } \\
\text { Mastery Based } \\
\text { Score }\left(\mathbf{M}_{\mathbf{x}}\right)\end{array}$ & $\begin{array}{c}\text { Students' } \\
\text { Vocabulary } \\
\text { Mastery Cycle I } \\
\left(\mathbf{M}_{\mathbf{x}}\right)\end{array}$ & $\begin{array}{c}\text { Students' } \\
\text { Vocabulary } \\
\text { Mastery Cycle II } \\
\left(\mathbf{M}_{\mathbf{x}}\right)\end{array}$ \\
\hline 1 & Noun & 70.00 & 76.25 & 84.38 \\
\hline 2 & Pronoun & 59.38 & 66.88 & 71.88 \\
\hline 3 & Adjective & 56.25 & 65.63 & 83.13 \\
\hline 4 & Verb & 60.63 & 69.38 & 78.12 \\
\hline 5 & Preposition & 59.37 & 63.12 & 76.88 \\
\hline
\end{tabular}

Table 6: The category or Level of the Students' Vocabulary Mastery of Based Score and Each Cycle 


\begin{tabular}{|c|l|c|c|c|}
\hline No & Indicators & $\begin{array}{c}\text { Students' } \\
\text { Vocabulary } \\
\text { Mastery Based } \\
\text { Score }\end{array}$ & $\begin{array}{c}\text { Students' } \\
\text { Vocabulary } \\
\text { Mastery Cycle I }\end{array}$ & $\begin{array}{c}\text { Students' } \\
\text { Vocabulary } \\
\text { Mastery Cycle }\end{array}$ \\
\hline 1 & Noun & Fair & Good & Good \\
\hline 2 & Pronoun & Fair & Fair & Good \\
\hline 3 & Adjective & Fair & Fair & Good \\
\hline 4 & Verb & Fair & Fair & Good \\
\hline 5 & Preposition & Fair & Fair & Good \\
\hline
\end{tabular}

Back to the above data, it can be seen the comparison of the students' vocabulary mastery from base score to their vocabulary mastery score of cycle II. In addition, the researcher and collaborator found that the most of the students' vocabulary mastery were higher than the base score except for their categories: The students' noun score for base score was $70.00 \%$ while on cycle I was $76.25 \%$ and cycle II was $84.38 \%$. The students' pronoun score for the base score was $59.38 \%$ while on cycle I was $66.88 \%$ and cycle II and cycle I was $65.63 \%$ and cycle II was $83.13 \%$. The student's verb score for base score was $60.63 \%$ while on cycle I was $69.38 \%$ and cycle II was $78.12 \%$. The students' preposition score for base score was $59.37 \%$ while on cycle I was $63.12 \%$ and cycle II was $76.88 \%$. From the students' vocabulary mastery test result, it can be concluded that the students' vocabulary mastery can be improved by using vocabulary notebooks.

\section{The Factors Influenced Students' Vocabulary Mastery by Using Vocabulary notebooks.}

The factors influenced students' vocabulary mastery by using vocabulary notebooks is caused by several aspects. First, the students' interest in using vocabulary notebooks, it was found from the field notes and interview done during the research which shown that they was interested and enjoyed to learn vocabulary by using vocabulary notebooks. Second, the students motivation in vocabulary, it also found from the field notes and interview done during the research which shown that they have more motivation to involve the vocabulary class. Third, the use of vocabulary notebooks, the vocabulary notebooks had given helpful contribution to the students in comprehending the text. Referring to the students' opinion, it can be concluded that vocabulary notebooks can make students easily understand about the text. And the last, the students' understanding about the text, with the aids of vocabulary notebooks the students can easily understand the text. It also gives influence to the improvement of students' vocabulary mastery. In short, factors influenced the improvement of students' vocabulary mastery are the students' interest, students' motivation, the use of vocabulary notebooks, and the students' understanding toward the text.

\section{CONCLUSIONS,IMPLICATIONS} AND SUGGESTIONS

Based on the findings, it can be concluded that teaching vocabulary by using vocabulary notebooks better improve the student's vocabulary 
mastery.While, the factors that influence the improvement of students' vocabulary mastery by using vocabulary notebooks are: the students' interest in using vocabulary notebooks, the students' motivation in vocabulary mastery, the use of the vocabulary notebooks are beneficial, and the students' understanding about the text

Based on the findings and conclusion, the following suggestions can be made: vocabulary notebooks can be used by teachers who have same problems about vocabulary in their effort to improve and increase their students' vocabulary. It also can be used by students who have the same problem with this research in their attempt to enlarge their vocabulary easily, and the last it can be used by other researchers to be one of the evidence in their action research.

\section{REFERENCES}

Dickinson, L. 1987. Self-Instruction in Language Learning. Cambridge: Cambridge University Press

Eckersley, C.E and J.M Eckersley. 196. A Comprehensive English Grammar for Foreign Students. London: Longman.

Fowle, Clyde. 2002. Vocabulary notebooks: implementation and outcomes. Retrieved from ELT Journal Volume 56/4 October 2002 COxford University Press on $10^{\text {th }}$ April, 2011 at $15.00 \mathrm{pm}$.
Gaims, R. and S. Redman. 1986. Working with Words. Cambridge: Cambridge University Press.

Gass, Susan M and Larry Selinker. 2001. Second language Acquistion. New Jersey: Lawrence Erlbaum Associates.

Gay, L.R and Peter Airisian. 2000. Educational Research: Competencies for Analysis and Application. New Jersey: Prentice Hall, Inc.

Harmer, Jeremy. 2004. How to teach English; an Introduction to the Practice of English Language Teaching. Edinburg Gate: Longman.

Hughes, Arthur. 2003. Testing for Language Teachers. Cambridge: Cambridge University Press.

Kemmis, Stephen and Robin McTaggart. 1988: The Action Research Planner. Victoria: Deakin University.

Leo, Sutanto. 2006. English For Leisure Time Speaking. Jakarta: Gramedia Pustaka Utama

McCrostie, James. 2007. Examining learner vocabulary notebooks. Retrieved from http://eltj.oxfordjournals.org/ content/61/3/246.abstract. on $10^{\text {th }}$ April, 2011 at $15.00 \mathrm{pm}$. 
Milss, Geoffrey E. 2003. Action research: A Guide for Teacher Researcher. New Jersey: Merril Prentice Hall.

Nunan, david. 1991. Language Teaching Methodology: a Textbook for Teacher. ELT Prentice Hall.

Puchta, H. and M. Scratch. 1993. Teaching Teenagers. Harlow: Longman.

Richard, Jack $\mathrm{C}$ and Willy A. Renandya. 2002: Methodology in Language Teaching; an Anthology of Current Practice. New York: Cambridge University Press.

Schmitt, N. 1997. Vocabulary Learning Strategies. Cambridge: Cambridge Universitu Press.

Schmitt, N. and D, Schmitt. 1995. Vocabulary notebooks: theorithical underpinnings and practical suggestions. Cambridge: Cambridge University Press.

Schmitt, N. and McCharty. 1997. Vocabulary Acquistion and Pedagogy. Cambridge: Cambridge University Press.

Sudijono, Anas. 2008. Pengantar statistic Pendidikan. Jakarta: Raja grafindo Persada.

Syah, Djalinus and Azimar Enong. 1982. Modern English
Grammar. Jakarta: Simplex Publishing Company.

Syaifullah. 2010. Improving students' Speaking Skill By Using Real Objects, Picturs, and Markers att the Second Year of English Education Departement Faculty of Education and Teachers Training Lancang Kuning University. Unpublished thesis. Pekanbaru : Padang University.

Walters, Jodee and Neval Bozkurt. 2009. The effect keeping vocabulary notebooks on vocabulary acquisition. Retrieved from http://ltr.sagepub.com on $10^{\text {th }}$ April, 2011 at 15.00 pm. 